\title{
Prosecutor's Authority in Conducting Auditing of State Losses Based on Law No. 16 of 2004 Concerning Prosecutors
}

\begin{abstract}
There are still various problems related to law enforcement in the field of state finance, one of which is related to overlapping legal principles, especially in the context of solving the problem of state losses in corruption. The purpose of this research is to analyze the legal consequences that should have been on the results of state loss audits by the Prosecutor's Office, based on case studies of the decision of the Central Jakarta District Court No.25/PID.SUS/TPK/2014/PN.JKT.PST. This research is normative legal research with a statutory approach, a case approach, and a conceptual approach. The legal material analysis technique is done by the method of interpretation. The results show that in the authority to calculate state losses, prosecutors should be guided by the fact that the Financial and Development Supervisory Agency (BPKP) is authorized to do so. Decision of the Constitutional Court No.31/PUU-X/2012. The Constitutional Court's decision was not made by the Prosecutor in No.25/PID.SUS/TPK/2014/PN.JKT.SUS. shows the prosecutor's inconsistency. Because before the prosecutor ignored the decision of the Constitutional Court No. 21/PUU-XII/2014 regarding the determination of the suspect as a pretrial object. The prosecutor considered that the decision was not legally binding because it surpassed the Constitutional Court's decision.
\end{abstract}

Anwar Sadat ${ }^{1}$, Prija Djatmika ${ }^{2}$, Bambang Sugiri ${ }^{3}$, Yuliati $^{4}$

1. Ph.D Candidate at Faculty of Law, Brawijaya University, Indonesia

2. Lecturer at Faculty of Law, Brawijaya University, Indonesia

3. Lecturer at Faculty of Law, Brawijaya University, Indonesia

4. Lecturer at Faculty of Law, Brawijaya University, Indonesia

Keywords: state loss, corruption, audit, prosecutor.

DOI: $10.7176 / \mathrm{JLPG} / 92-24$

Publication date: December $31^{\text {st }} 2019$

\section{A. Introduction}

State finance has an important role in the implementation of state functions, including in Indonesia. Indonesia as a rule of law has a function to achieve the goals of the country it aspires for. This function is contained in the fourth paragraph of the opening of the 1945 Constitution of the Republic of Indonesia. The country's main function is to protect all Indonesians and all of Indonesia's blood spills, promote public welfare, educate the nation's life, and participate in carrying out world order. With this function, the administration must try to carry out various activities to carry out this function. Then the state must also regulate funding sources so that all activities related to state functions can run optimally. Therefore, Indonesia drafted a set of regulations relating to the implementation of state finances which came to be known as state financial law. State finance law has a clear legal source that is contained in Article 23-23E of the 1945 Constitution of the Republic of Indonesia. With these various laws and regulations, it is expected that the implementation of state financial management can be directed and not cause problems. However, there are still various problems related to law enforcement in the field of state finance. Many problems that arise mainly related to efforts to prevent state losses. One of the problems that occurred related to overlapping legal principles, especially in the context of solving the problem of state losses. This is closely related to corruption. With the concentration of power, authority and responsibility in administering the state and weak community participation in carrying out social control functions are one of the factors causing increased corruption in Indonesia. Another factor that is often considered to be the cause of widespread corruption is the factor of corruption that occurs in Indonesia, which is considered to be "entrenched" and an inseparable part of people's daily lives.

Loss on state finances is one of the fundamental elements in criminal acts of corruption, therefore to determine the existence of state financial losses, it is necessary to have a clear definition of juridical definition of state finances with certainty. ${ }^{1}$ In the various laws and regulations that currently exist, the definition of state losses has a different understanding between one law and another, as in Law Number 17 of 2003 concerning State Finance, the provisions of Article 1 number 1 explain that what is meant by "State finances are all rights and obligations of the state that can be valued in money, as well as everything in the form of money or in the

\footnotetext{
${ }^{1}$ Hartanti, E., (2009). Tindak Pidana Korupsi. Semarang: PT.Sinar Grafika, p. 25.
} 
form of goods that can be owned by the state due to the implementation of these rights and obligations". ${ }^{1}$ Whereas the definition of state finance as referred to in the Elucidation of Article 2 and Article 3 of Law Number 31 of 1999 concerning Eradication of Corruption is "all state assets in whatever form are separated or are not separated including all parts of state assets and all rights and obligations that arise, because they are in the control, management and accountability of state agency officials, both at the central and regional levels, and are in the control, management and responsibility of State-Owned Enterprises / Regional-Owned Enterprises, foundations, legal entities and companies that include state capital, or companies that include third-party capital based on agreements with the State". 2

So it can be concluded from the understanding of the Law on State finance, basically in line. Because state finance is not solely in the form of money as Law Number 17 of 2003 Concerning State Finance but includes all rights and obligations (in any form) that can be measured in monetary value. The definition of state finance also has a broad meaning which includes state finance originating from the State Revenue and Expenditure Budget, Regional Revenue and Expenditure Budget, State-Owned Enterprises, Regional-Owned Enterprises and in essence all state assets as a State financial system. Law Number 31 of 1999 concerning Eradication of Corruption.

The absence of uniformity, confusion, and misunderstanding of state finances and state losses have brought legal uncertainty and ultimately hampered economic development. This country's financial problems still often confuse, especially in efforts to eradicate corruption. But then through the process approach, state finance can be interpreted as any activity or activities that are closely related to money received or formed based on state privileges for the public benefit. The focus on eradicating criminal acts of corruption cannot be released with state losses as a form of violation of broad social and economic rights. Therefore investigators or prosecutors as government agencies that carry out state power in the field of prosecution, in carrying out their duties should be independent regardless of the influence of government power and the influence of other powers.

The basic thinking of preventing the emergence of state financial losses has naturally pushed for both criminal and civil methods, to seek maximum and speedy return of all state losses caused by corrupt practices. This basic thinking has given the contents and meaning of Articles in Law Number 31 of 1999 concerning The Eradication of Corruption. State losses or the state's economy are the main elements of corruption offenses. ${ }^{3}$ Based on the description of the problem above, a study was conducted to analyze the legal consequences that should have been on the results of the state loss audit by the Prosecutor's Office, based on a case study of the decision of the Central Jakarta District Court Number 25/PID.SUS/TPK/2014/PN.JKT.PST.

\section{B. Research Method}

This research is analytical juridical-normative research that is descriptive in nature, by describing and analyzing applicable laws and regulations and legal theories related to cases discussed in their implementation practices relating to the problems to be examined. This research approach is the Law approach, case approach, and concept approach. ${ }^{4}$ The legal materials used in this study consist of three legal materials, namely primary, secondary and tertiary legal materials. ${ }^{5}$ Primary legal materials are binding legal materials, such as Law Number 16 of 2004 concerning Prosecutors. Secondary legal materials are the factors that influence Law Enforcement or the like used in this research writing material. ${ }^{6}$ Tertiary legal materials are taken from the Indonesian public dictionary, legal dictionary, and English dictionary. ${ }^{7}$ Legal material analysis technique using the method of interpretation.

\section{Results and Discussion}

\section{Position of the Prosecutor's Office in the Indonesian State Administration System}

\footnotetext{
${ }^{1}$ Indonesia, Law Number 17 Year 2003 Regarding State Finance, Article 1 number 1.

${ }^{2}$ Indonesia, Law Number 31 of 1999 Concerning Eradication of Corruption, Article 2 and Article 3.

${ }^{3}$ Atmadja, A.P.S. (2010). Keuangan Publik dalam Persfektif Hukum Teori, Praktik dan Kritik, Third Edition Jakarta: Faculty of Law, University of Indonesia, p. 4.

${ }^{4}$ Marzuki,P.M. (2011). Metode Penelitian Hukum. Jakarta: Kencana, p. 93.

${ }^{5}$ Soekanto, S. and Sri Mamudi. (2012). Penelitian Hukum Normatif Suatu Tinjauan Singkat. Jakarta: Raja Grafindo Persada, p. 12-13.

${ }^{6}$ Ibid., p.77

${ }^{7}$ Nisa, K. (2013). Tanggung Jawab Notaris Sebagai Pejabat Urnurn Dalarn Perkara Pidana Mengenai Akta Yang Dibuatnya. Malang: University of Brawijaya, p. 31.
} 
The existence of the Attorney General's Office of the Republic of Indonesia is not explicitly regulated in the 1945 Constitution of the Republic of Indonesia before the amendment, but only implicit. Law number 5 of 1991 concerning the Attorney General's Office of the Republic of Indonesia, as a sub-ordinate of the 1945 Constitution of the Republic of Indonesia, formulates the existence of the Republic of Indonesia's Attorney's Office in weighing considerations which states "that to increase efforts to renew national law in the Republic of Indonesia as A constitutional state based on the Pancasila and the 1945 Constitution, it is deemed necessary to strengthen the position and role of the Attorney General's Office of the Republic of Indonesia as a government agency implementing state power in the prosecution in the power structure of law enforcement bodies and justice.

Fundamental changes occurred after the issuance of Law Number 6 of 2004 concerning the Attorney General of the Republic of Indonesia, which replaced and revoked Law Number 5 of 1991, in the preamble of considering that it was stated "that to further strengthen the position and role of the prosecutor's office of the Republic of Indonesia as a government agency implementing powers The state in the field of prosecution must be free from the influence of power from any party. Secondly, this law shows that the existence of the Indonesian prosecutor's office in law enforcement efforts cannot be ignored. This is because, in addition to normatively regulating, also on a factual level, the public wants law enforcement agencies to play a role so that a sense of justice, certainty can be realized. law, and the use of law in the life of society, nation, and state.

By following the development and demands of the times, the AGO should be able to carry out the reform of the times in various fields of life, especially in the field of law enforcement to realize the identity of the Prosecutor's Office of the Republic of Indonesia which is more professional and more professional. The Prosecutors' Office is also demanded to not only carry out its functions properly but also must be able to establish its identity as one of the "institutions of implementing State power", not an instrument of power of the authorities. In the course of history, after the replacement of the Het Herziene Inladsch Regulation (HIR) staatsblad Year 1941 Number 44 Jo Law Number 1 Dirt Year 1951 with Law Number 8 of 1981 concerning Criminal Procedure Code (KUHAP), the prosecutor's authority in law enforcement is related with the investigation as regulated in article 39 HIR almost entirely revoked, even with the issuance of Law Number 30 Year 2002 concerning the Corruption Eradication Commission, the authority in the field of prosecution is no longer the monopoly of the prosecutor's office. Such an arrangement will have implications for the existence of the prosecutor's office of the Republic of Indonesia in implementing law enforcement.

Despite the change of name and government, the prosecutors' functions and duties remain the same, namely prosecuting criminal cases and acting as plaintiffs or defendants in civil cases. ${ }^{1}$ Law No. 8 of 1981 concerning the Criminal Procedure Code, strictly separates functions relating to investigations, prosecutions, and examinations in the trial process even though the Indonesian prosecutor's office is still given the authority to conduct investigations on Corruption Crimes as stated in article 284 paragraph (2), but only temporary. When Law Number 2 of 2002 concerning the National Police of the Republic of Indonesia and Law Number 30 of 2002 concerning the Corruption Eradication Commission were put into effect, the function of the investigation of Corruption Crimes which had been part of the tasks and authority of the Indonesian Attorney Office also experienced changes. Ironically, lawmakers act ambiguously because the resulting legislative products do not have a clear philosophical foundation to cope with the problem of implementing the law (ius constutuenden).

Specifically relating to the eradication of corruption, before the issuance of Law Number 30 of 2002 concerning the commission to eradicate corruption, the government has formed several institutions, including the corruption eradication team (TPK) of 1967-1982 under the control of the attorney general. Since the KPK has not yet been formed until its completion, discordant voices have surfaced because of fears of a sectoral ego, given its enormous authority as a Super Body (superpower) institution. Besides, the KPK has no procedures/mechanism restrictions, particularly in examining State officials and bank secrets. The KPK can take over the investigation of corruption by the police and prosecutors. The KPK's enormous authority is feared to cause conflicts of interest between institutions that have the same authority.

On the one hand, there are indeed essential changes regarding the position of the Republic of Indonesia prosecutor's office, namely in Law No. 15 of 1961 the Indonesian prosecutor's office was designated as a "state tool", while in Law No. 5 of 1991 and Law No. 16 of 2004 defined as "government institutions". On the other hand, these three laws regulate the position of attorney general who is appointed at the level of the Minister of State and becomes the president's assistant. In Law Number 15 of 1961 article 5 of Law Number 5 of 1991

${ }^{1}$ Ibid., p. 121. 
article 19 and Law Number 16 of 2004 article 19 paragraph (2) it is stated that the attorney general is a presidential aide because he is appointed and dismissed by the president and is responsible to the president.

Looking at the above arrangements, it can be explained that the position of the prosecutor's office as a government agency that exercises state power in the field of prosecution, when viewed from a standpoint, implies that the prosecutor's office is an institution that is within executive power. Meanwhile, when viewed from the side of the prosecutor's authority in carrying out prosecutions, it means that the Prosecutor's Office exercises judicial power.

Based on the explanation above, it can be said that Law Number 16 Year 2004 places the Prosecutor's Office in an ambiguous position. On the one hand, the Prosecutor's Office is demanded to carry out its functions and authority independently, on the other hand, the Prosecutor's Office is put under custody because the position is under executive power. Herein lies the weaknesses in the regulation of this Law. If the government (President) has a commitment to uphold the rule of law in Indonesia, it will not be a problem if the Prosecutor's Office remains in the executive environment, provided that the Prosecutor's Office is empowered by being given broad and professional authority and responsibilities. If the Government does not have such commitment, it would be better if the Prosecutor's Office was placed as an independent and independent "state agency".

\section{State Financial Losses Determined by Prosecutors and Judges Concerning Criminal Punishment} in the Corruption Court Decision No.25/PID.SUS/TPK/2014/PN.JKT.SU

Regarding the issue of the authority to calculate state financial losses in a criminal act of corruption, there is legal uncertainty, the agency conducting the calculation further states that "There is legal uncertainty in handling cases of corruption due to unclear definition of state financial losses which also implies which institutions are entitled and the authorities declare that there has been a state loss. The formulation of this state loss is used as an element in corruption cases which must be proven in a trial.

There are times when to prove the existence or absence of state financial losses, however, the Police investigator and the Prosecutor's Investigation sometimes have their own calculations and are not based on the BPKP audit results in calculating the amount of state financial losses alleged, as in the case charged with Ucok Bangsawan as the Authorization of Regional Budget Users (SKPD) in Kramat Jati sub-district in 2014, where the Defendant was sentenced to 1.6 months by the Panel of Judges of the case, without any definite basis for fulfilling the element of "state loss". If consistently adhering to the teachings against formal law by following the decision of the Constitutional Court No. 003/PUU-IV/2006, the Supreme Audit Board (BPK) is the most authorized institution to determine the loss of the State."

\section{State Financial Losses based on Prosecutor's Calculation Results in Case No.25/PID.SUS/TPK/2014/PN.JKT.SUS.}

In the practice of investigation and prosecution, the textual law does not include the agency that counts "state financial losses" in corrupt acts, there are "agencies that determine state losses", arrangements relating to the authority to calculate state financial losses in corruption can be seen from the approach of several laws and regulations. In the elucidation of Article 32 of the Anti-Corruption Act only states that "losses of state finances are losses that can be calculated in an amount based on the findings of the competent agency or appointed public accountant". This phrase refers to the need for a body or accountant authorized to determine state losses. But in practice, the uncertainty about "the authorized agency or appointed public accountant" can lead to multiple interpretations. The phrase "authorized agency" can be translated as an authorized agency or has the capacity in the field of accounting or calculating state financial losses or can also be interpreted as an authorized institution in handling corruption cases.

In terms of parameters testing the legality or validity of the evidence "conclusions of state financial losses from the Attorney General's findings", it is necessary to re-examine the formulation according to Prof. Philipus M. Hadjon, ${ }^{1}$ seen from "Rechmatig Bestuur", it is stated in more detail that "Rechmatig bestuur is the principle of government which rests on the principle of the rule of law, namely the principle of legality. Based on the concept of rechmatig bestuur, the writer will use it as an analytical tool to test the legality or validity aspects of the use of evidence from the prosecutor's count as follows:

a. Calculation of financial losses seen from the demands of the Public Prosecutor in the Decision No.25/PID.SUS/TPK/2014/PN.JKT.SUS.

${ }^{1}$ Hadjon, and et al. (2011). Hukum Administrasi dan Tindak Pidana Korupsi. Yogyakarta: Gajah Mada University Press, p. 21. 
1) The calculation of state financial losses based on attributive authority (formal investigative audit/audit assignments) does not exist, only through non-attributive authority, namely through the verbal system.

2) The calculation of state financial losses is based on non-audit investigative procedures. (There is no Expert Institution that assesses state losses in Aquo cases)

3) The caculation of budget use by Kramat Jati District, containing the budget conclusions used for Kramat Jati District "no known of state finance" as referred to in clause Article 2 and Article 3 of Law Number 31 of 1999.

b. Determination of State Financial Losses seen from the Prosecutor's Indictment and Judge Considerations in the Corruption Court Decision there are 4 (four) characteristics of determining the financial losses of the state by the judge in the Corruption Court Trial namely:

1) Whereas, on the orders of the Defendant of the SKPD, then witnesses, cut the budget disbursed since 2009-2013, while the prosecutor used the calculation of state losses based on the disbursement of the regional budget, but eliminated the essence of utilization for the benefit of the District (is the State)

2) Determination of the amount of state financial losses by the Prosecutor, Judge Considerations and Court Decisions is IDR. 609,446,546, then the value is used by the Budget User for the benefit of the District of Kramat Jati;

3) Determination of the amount of state financial losses ", Judge Considerations and Court Decisions. Because the approval of the sub-district head for the $25-30 \%$ budget cuts, has resulted in the activities in the DPA not being able to be carried out optimally. (there is no evidence that DPA is obstructed (or the results of an audit), even the authority to use the budget is SKPD insofar as it can be accounted for, including and not limited to the interests of the State).

Application of the elements that are detrimental to state finances in the offense of criminal acts of corruption No.25/PID.SUS/TPK/2014 /PN.JKT.SUS

The same thing also happened in the trial of corruption case No.25/PID.SUS/TPK/2014/PN.JKT.SUS. on the use / allocation of APBD funds in Kramat Jati sub-district with defendant Ucok Bangsawan, there is a misunderstanding from the Judge in determining the fulfillment of the State's financial loss element to the $s u b$ district head policy of making a 30\% deduction from the Budget allocation for activities, at the Central Jakarta Corruption Court hearing.

Whereas in the decision and result of the Attorney General's investigation, there was no evidence of an investigative audit or expert statement that had competence in the state finances or APBD, but both the Prosecutor's Office (JPU) and the judges' panel immediately concluded that there was a loss of the State committed by the Defendant. the Prosecutor and the Panel of Judges firmly stated that in their consideration, the $30 \%$ deduction had been made since the Defendant was not in the office, even with the Prosecutors expressly stated that the budget deduction was allocated for the interests of Kramat Jati District.

The defendant's actions should have been detrimental to or detrimental to state finances, through the BPKBPKP audit results, so that state losses of Rp 609,446,546 were not legally flawed. However, the Prosecutor only used the results of the subsequent examination to conclude immediately, that the Investigation examination was the result of an audit by the Prosecutor, if the Prosecutor had conducted an Audit, it should not have stopped at one Defendant, because the 30-25\% deduction of APBD funds had actually occurred long before the Defendant served as the Head of Kramat Jati Sub-district, even more so in the period of the Defendant whose character was to continue the existing policy, withholding 30-25\%. The fact was that the Defendant used the interests of the District and not for the benefit of enriching himself as an official. Besides, an audit by a prosecutor, in principle, is not a state institution whose task is to evaluate the state revenue budget, including if there is a state loss and corruption. To be balanced and transparent, meaning that it is not one-sided from government to government, Public Accountants can evaluate. Although the Public Accountant does not have a government, he is recognized for the validity of his actions. The losses to the state are not solely calculated by state institutions, but there are also other institutions that control them.

\section{Calculation of State Financial Losses by the Prosecutor's Office or the Court}

Because the Corruption Act specifically Article 2 and Article 3 does not explicitly mention who the agency or party has authority in determining the calculation of state losses, in practice, there also occurs judges and prosecutors in calculating state financial losses in corruption cases. In the corruption case The use of APBD funds which was cut by the Kramat Jati Sub-district, the Panel of Judges of the Central Jakarta District Court, determined the existence of state financial losses in the case was only based on the testimony of the Treasurer 
witness from the Budget User Authority. Whereas in its consideration the Panel of Judges stated that Considering, that based on the statements of witnesses presented by the public prosecutor and witnesses Ade Charge (Rd. Siti and Veny) and the defendant's statement as well as the evidence that had been confiscated and had also been shown in this case trial, obtained legal facts as follows ${ }^{1}$ :

- That the defendant who served as the sub-district head of East Java, East Jakarta from 2009 to June 2013 had made a policy in managing the budget, namely by following the old pattern, there was a $30 \%$ deduction for each activity.

- That the $30 \%$ deduction policy had been carried out since the previous sub-district head, then the defendant continued the policy.

- That the period of the previous sub-district head was as follows:

1. From 1997 to 2000 sub-district head Kusnan A Halim

2. From 2000 to 2007 sub-district head Sarodi

3. 2002 to 2003 Sub-District Head Suwardi Hasan

4. From 2003 to 2005 sub-district head Krisdayanto

5. From 2005 to 2007 sub-district head Sabeni

From the above considerations, the Assembly recognizes the exact number of losses to the state, but the assembly believes that state finance in the Aquo case is actually used for the benefit of the District. These considerations answer the argument of lawyer Ucok Bangsawan who stated that the state loss had not yet been found in the use of the Budget. In its consideration, the panel of judges stated that they could determine state losses. Judging the calculation of state financial losses, without going through procedural audits, clearly creates a polemic. Besides, because there are no regulations governing the authority of judges in counting or loss. ${ }^{2}$ In this case, The application of the element of detrimental to state finances in the offense of criminal acts of state corruption, the determination of state losses by potential judges is wrong because in practice judges and courts do not carry out financial audit tasks.

A lecturer in state finance law at the University of Indonesia's Faculty of Law, Dian Puji Simatupang, said that judges were not auditors, so they could not determine state losses. Formally, state losses must be proven by the calculation by the auditor through a standard mechanism in auditing state finances. So the judge did not have knowledge about the mechanism of state financial calculations.

\section{Alternative Authorities in Calculating State Financial Losses}

In addition to the authorized institution or institution, one alternative party that can calculate the loss of state finances is the accountant as a profession. State finance is calculated and managed by a professional person known as the State Accountant, who works at the Ministry of Finance as the Office of the State General Treasurer. ${ }^{3}$ Thus, if there is a loss of state finances, the ones who must do the calculations are also professionals who have sufficient competence to determine the amount of the loss. The profession referred to is the Accountant who has a state register (locally) or chartered accountant (at the international level).

Hutabarat, BPKP Central Java Auditor, Local Workshop "Study of the elements of state financial losses in the Corruption", Semarang 5 November 2013. ${ }^{4}$ State finance is calculated and managed by a professional person known as the State Accountant, who works at the Ministry of Finance as the Office of the State General Treasurer. Thus, if there is a loss of state finances, the ones who must do the calculations are also professionals who have sufficient competence to determine the amount of the loss. The profession referred to is the Accountant who has a state register (locally) or chartered accountant (at the international level).

A professional accountant according to the Indonesian Institute of Accountants, must fulfill his responsibilities with the highest standards of professionalism, achieve the highest level of performance, with an

\footnotetext{
${ }^{1}$ Copy of Decision of Central Jakarta District Court No Number: 25/PID.SUS/TPK/2014/PN.JKT.SUS. Dated July 17, 2014: in consideration of pages 92-93.

${ }^{2}$ Hukumonline. (2012). Kontroversi Akuntan Publik Menghitung Kerugian Negara, available at www.hukumonline.com. accessed on November 15, 2013.

3 Yutho, and et al.(2014). "Penerapan Unsur Merugikan Keuangan Negara dalam Delik Timdak Pidana Korupsi”, Policy paper Indonesia Corruption Wacth, Jakarta, p. 64.

${ }^{4}$ Hutabarat, (2013). "Kajian unsur kerugian keuangan negara dalam delik tipikor". Presented in the Forum Discussion "Kajian unsur kerugian keuangan negara dalam delik tipikor", Semarang November 5, 2013.
} 
orientation towards the public interest. To be able to realize this, four basic needs must be fulfilled by an accountant as follows:

1. Credibility: people need information credibility and information systems.

2. Professionalism: required individuals who can clearly be identified by accountant service users as professionals in the accounting field.

3. Service Quality: there is a belief that all services obtained from accountants are provided with the highest performance standards. ${ }^{1}$

1. Trust: accountant service users must be confident that there is a professional ethical framework underlying the service delivery by accountants.

\section{Conclusions}

Regarding the authority to calculate state losses, prosecutors should be guided, that the Financial and Development Supervisory Agency (BPKP) has the authority to do so. Decision of the Constitutional Court (MK) No. 31/PUU-X/2012. The Constitutional Court's decision was not made by the Prosecutor in Number: 25/PID.SUS/TPK/2014/PN.JKT.SUS. shows the prosecutor's inconsistency. Because, before the prosecutor ignored the decision of the Constitutional Court No. 21/PUU-XII/2014 regarding the determination of the suspect as a pretrial object. The prosecutor considered that the decision was not legally binding because it surpassed the Constitutional Court's decision. Calculation of state financial losses that are only carried out by prosecutors, as in Case No. 25/PID.SUS/TPK/2014/PN.JKT.PST on behalf of Defendant Ucok Bangsawan, based only on the assumptions and methods of the prosecutor himself during the investigation and investigation of the case, without referring to a standard calculation method and is feasible. Only based on witness testimony. From this point of view, it can be seen that the prosecutors indicated that the investigation and prosecution processes were not appropriate, "in fact expert witnesses should have been presented to present their legal arguments.

\section{Reference}

Atmadja, A.P.S. (2010). Keuangan Publik dalam Persfektif Hukum Teori, Praktik dan Kritik, Third edition. Jakarta : Faculty of Law, University of Indonesia.

Hadjon, and et al.. (2011). Hukum Administrasi dan Tindak Pidana Korupsi. Yogyakarta : Gajah Mada University Press.

Hartanti, E. (2009). Tindak Pidana Korupsi. Semarang : PT.Sinar Grafika.

Hukumonline. (2012). Kontroversi Akuntan Publik Menghitung Kerugian Negara, available at www.hukumonline.com. (November 15, 2013).

Hutabarat. (2013). Kajian unsur kerugian keuangan negara dalam delik tipikor. Presented in the Discussion Forum “Kajian unsur kerugian keuangan negara dalam delik tipikor”, Semarang: November 5, 2013.

Indonesian District Court. Copy of Decision of Central Jakarta District Court No Number: 25/PID.SUS/TPK/2014/PN.JKT.SUS. July 17, 2014: under consideration.

Nisa, K. (2013). Tanggung Jawab Notaris Sebagai Pejabat Urnurn Dalarn Perkara Pidana Mengenai Akta Yang Dibuatnya. Malang: Universitas Brawijaya.

Nugroho, L.(2013). Mengkaji Ulang keberadaan Unsur Merugikan Keuangan Negara dalam Delik Tindak Pidana Korupsi. Presented in the Focus Group Discussion "Mengkaji Ulang keberadaan Unsur Merugikan Keuangan Negara dalam Delik Tindak Pidana Korupsi”, September 17, 2013.

Marzuki, P. M. (2011). Metode Penelitian Hukum. Jakarta: Kencana.

Soekanto, S. and Mamudi, S. (2012). Penelitian Hukum Normatif Suatu Tinjauan Singkat. Jakarta: Raja Grafindo Persada.

\footnotetext{
${ }^{1}$ Nugroho, L. (2013). Mengkaji Ulang keberadaan Unsur Merugikan Keuangan Negara dalam Delik Tindak Pidana Korupsi". Presented in the Focus Group Discussion "Mengkaji Ulang keberadaan Unsur Merugikan Keuangan Negara dalam Delik Tindak Pidana Korupsi”, September 17, 2013.
} 
Yudho, E., and et al., (2014). Penerapan Unsur Merugikan Keuangan Negara dalam Delik Timdak Pidana Korupsi. Policy paper Indonesia Corruption Wacth.

\section{Laws And Regulations}

Indonesia, Law Number 31 of 1999 concerning Eradication of Corruption.

Indonesia, Law Number 17 of 2003 concerning State Finance.

Indonesia, Law Number 1 of 2004 concerning the State Treasury.

Indonesia, Law Number 16 of 2004 concerning the Prosecutor's Office.

Indonesia, Law Number 15 of 2006 concerning the Supreme Audit Board

Indonesia, Law Number 46 of 2009 Concerning Corruption Court. 